\title{
Social User Behavior Analysis of Purchasing Decisions in Instagram Online Store
}

\author{
${ }^{1}$ Hans Kristian, ${ }^{2}$ Stefan Gendita Bunawan, ${ }^{3}$ Gunawan Wang, ${ }^{4}$ Sfenrianto Sfenrianto \\ Information System Management Department, BINUS Graduated Program - Master of Information Systems \\ Management, Bina Nusantara University, Jakarta, Indonesia, 11480. e-mail: ${ }^{1}$ hans.kristian001 @ binus.ac.id; \\ ${ }^{2}$ stefan.gendita@ binus.ac.id; ${ }^{3}$ gwang@ binus.edu; ${ }^{4}$ sfenrianto@ binus.edu.
}

\begin{abstract}
The Instagram application is currently developing into a social commerce (s-commerce) in Indonesia, where many small and medium scale entrepreneurs use the application to sell their products. This study examines behaviors in individuals to the popular social networking site Instagram. The influence of social media behavior on purchasing decisions in e-commerce using the usefulness, perceived of use, social media behavior factors against intention to buy into the Technology Acceptance Model (TAM) model theory. The results showed that the TAM model had a significant effect on the consumer's intention to purchase the product through the Instagram (Intention to Buy).
\end{abstract}

Key words : Social Media Marketing, TAM, Instagram, Customer's Behavior

\section{INTRODUCTION}

The development of the Indonesian economy is currently very rapidly developing and growing. Economic growth in Indonesia, which is currently developing, is the emergence of many digital technology-based creative economic industries. One of the developing digital creative economy industries today can be seen with the emergence of a good deal of e-commerce marketplace companies, digital payments, digital financing, digital transportation. The emergence of the digital creative economy industry in Indonesia is very welcomed by the people in Indonesia with an ever-increasing rate of growth. The development of the digital era with the internet created a creative idea in the world of marketing, making the emergence of the new wave marketing era. For business people in Indonesia, they are currently paying attention to the development of the industrial revolution era so that their companies can continue to exist in trade in Indonesia and be quick in making decisions to determine strategies in the future. Companies in Indonesia today certainly have a goal that a product that is owned by a brand is expected to be widely known by the wider community in Indonesia as effectively and efficiently as possible.
Companies that are currently watching the development of the industrial revolution are developing strategies, namely digital marketing. This digital marketing functions within a company in order to market its products by providing information, creating community forums, supporters or followers, to increase the value or success of a brand. Digital marketing is the use of the internet as a technology that can connect two-way communication between companies and consumers (Coviello, 2001). Social media can also be a tool that can be used to disseminate information in the form of text, images, audio and video (Kotler, 2012).

The success of using social media as a promotional media depends on how consumers accept the technology. This is supported by the model theory of Technology Acceptance Model (TAM), a theory as a foundation for learn and understand user behavior in accepting and using information system (Handayani, 2007) [1]. The TAM model was developed based on the TRA model. "The TRA model can be applied because decisions made by individuals to accept an information technology are conscious actions that can be explained and predicted by their behavioral intentions" (Jogiyanto, 2013, p. 111) [2]. TAM argues that individual acceptance of information technology systems is determined by these two constructs.

\section{RELATED WORK}

\section{A. Digital Marketing}

It is one way to promote products and services using the Internet. Besides being able to promote the product, Internet marketing is also done to increase sales, improve branding, and nurture relationships with consumers. Ultimately, all of these strategies aim to capture more consumers and profits can increase.

The importance of Digital Marketing for companies is the influence for consumers to get the information value of a product and make a decision whether they need to buy the item or not, this is to indicate the information provided in the process [3]. Coviello, Milley, Marcolin (2001) — Digital marketing is the use of the internet and to create and connect 
Hans Kristian et al., International Journal of Emerging Trends in Engineering Research, 8(2), February 2020, 598 - 601

dialogues between identified companies and consumers. Urban (2004) —Digital marketing is a way to improve and expand the functions of traditional marketing using the internet and information technology. Ridwan Sanjaya dan Joshua Tarigan (2009) - Digital marketing is marketing or branding activities using various web-based media, such as websites, blogs, e-mails, adwords, and social networking.

\section{B. Social Media Marketing}

In the opinion of Zarella (2011: 51), published in the book Social media that there are $4 \mathrm{Cs}$ in operating social media, including:

a.) Context is a grammar, form or framework of how we deliver messages to the audience with a certain format. Context really determines the meaning of a word, if the context changes then the meaning of a word also changes. Pragmatics view context as shared knowledge between speech and listener and that knowledge leads to the interpretation of a speech. Specific knowledge or context can cause humans to identify different types of speech acts. Context features include eight things. The eight relevant context characteristics are the speaker, speech partner, speech topic, time and place of speech, channel or media, code (dialect or style), message or message, and event or event.

b.) Communications is the process of delivering a message by someone to someone else to tell, change attitudes, opinions, or behavior, both verbally (directly) or indirectly (through the media) to match what the message provider wants, which meets the five WHO elements: what, in which channels, for whom, with what effect. In social media, communication is a practice in conveying or sharing (sharing) as well as listening, responding, and developing messages to the public in unlimited distance and time.

c.) Collaboration is an activity in which two or more parties work together by contributing knowledge, experience, and the ability of each to achieve a common goal that produces an effect or benefit to the parties involved. In short, collaboration is working together between the giver and receiver of the message interactively so that the message conveyed is more effective and efficient. The values that underlie a collaboration are the same goals, common perceptions, willingness to process, mutual benefits, honesty, compassion and community-based.

d.) Connections is the relationship that is established and maintained continuously between the giver and receiver of the message.

\section{Instagram}

One of the several types of social media available, Instagram is an internet-based service as well as a social network for sharing stories via digital images. Gadgets users often use this network to directly share their shots (Sulianata, 2015: 119). The Instagram application was first launched in October 2010 and was intended only for Apple mobile operating (IOS). Instagram released its Android version in
April 2012. An increase active user each year brings Instagram through 1 billion in June 2018 (Kompas.com). With features provided by Instagram such as IGTV and Instagram Stories, changing marketing trends becomes more interesting. With this attractive advertising platform design, the Instagram application has succeeded in attracting $70 \%$ of its users to buy products online (sproutsocial.com). According to a survey conducted by Instagram and the IPSOS Institute, $87 \%$ of SME businesses have succeeded in increasing sales and $82 \%$ of them receive messages through direct messages (DM) from customers on Instagram every day (dailysocial.id). Salpini [4] conducted a study of Instagram users, from a survey conducted that 72 percent of Instagram users were interested in buying products from what they saw in advertisements and concluded that Instagram was a social media that was quite influential in online buying and selling transactions.

\section{Technology Acceptance Model (TAM)}

The Technology Acceptance Model is an information systems theory that models the process of users willing to accept and use technology. Such a model proposes that when users are offered to use a new system, a number of systems influence the user's decision about how and when to use the system [5] The technology acceptance model (TAM) built to understand the factors that influence the acceptance of the use of computer technology. Modification of the TAM model was carried out by Venkantesh (2002) by adding a trust variable with the title: Trust enhanced Technology Acceptance Model, which examined the relationship between TAM variables and trust.

\section{Technology acceptance model}

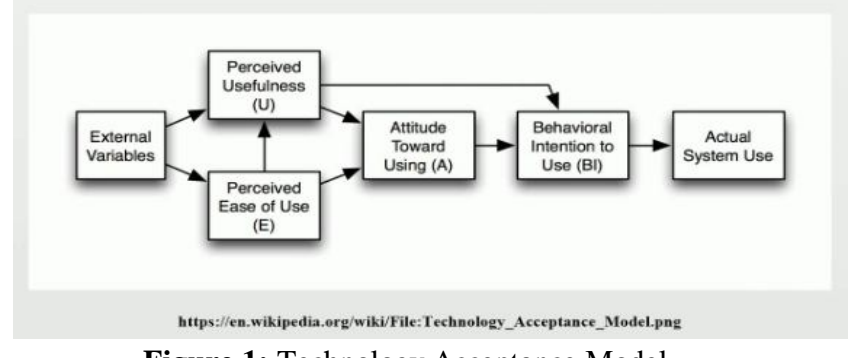

Figure 1: Technology Acceptance Model

\section{Perceived Usefulness (PU)}

Perceived usefulness according to Davis in Surachman (2013) is a belief from someone that by using a particular information technology system will improve the performance of his work. Furthermore according to Venkatesh and Davis in Devi and Suartana (2014) perceived usefulness is the level of individual confidence that technology will enhanced its performance. Perceived usefulness is the extent of trust in technology that can help to improve their performance. 
Hans Kristian et al., International Journal of Emerging Trends in Engineering Research, 8(2), February 2020, 598 - 601

\section{Perceive Ease of Use (PEU)}

Perceived Ease of Use is a variable that measures the level of trustworthiness in system usage and is independent of effort (Davis, 1989). PEU is the extent to which someone believes that using a technology will be free from effort. From this definition, it is known that this perceived ease of use construct is also a belief about the decision-making process. If someone feels that the information system is easy to use, he will use it. Conversely, if someone feels that the information system is not easy to use then he will not use it. Venkatesh and Davis [6] said that job relevance is "an individual's perception regarding the degree to which the target system is applicable to his or her job" (p.191). Similarly, this study proposes that job relevance influences perceived ease of use and perceived usefulness.

\section{Intention to Buy}

Intention to Buy is a behavioral tendency to have a desire to buy. According to Peter and Olsen (2000) intention is a plan to engage in a specific behavior to achieve goals. According to Cobb-Walgren, Ruble, and Donthu (1995) buying interest is a mental statement from consumers that reflects the purchase plan of a product in certain brands. Basically, if someone intends to buy is usually influenced by factors such as encouragement and certain considerations. Dodds, Monroe, and Grewal (1991) suggest that buying interest is defined as the likelihood of a person buying a particular product that he sees.

\section{RESEARCH METHOD}

\subsection{Overall Framework}

In this research, the data collected is by distributing questionnaires, with quantitative approach i using non-probability sampling with quota sampling technique. With the TAM model obtained from previous studies, the following TAM models in this research model are:

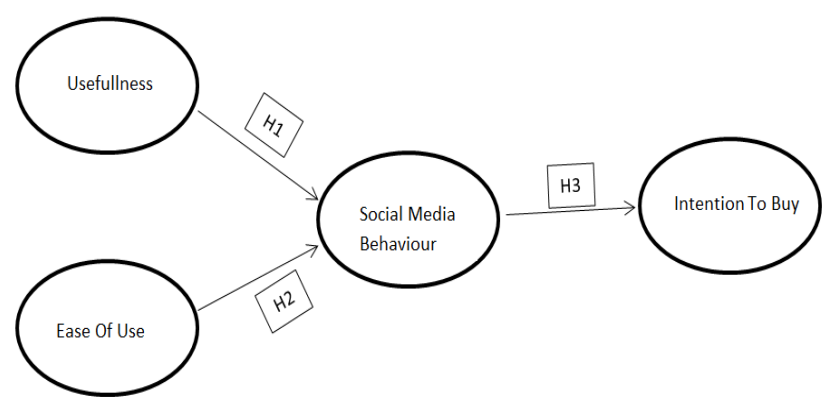

Figure 2: Research Method

\subsection{Hypothesis}

- H1: Effect of Usefulness on Social Media Behavior

- H2: Effect of Ease of Use on Social Media Behavior

- H3: Effect of Social Media Behavior on Intention to Buy

\subsection{Questionnaire}

The questionnaire method used in this study is based on the measurement scale used in TAM [7] and literature with some modification and change of words needed to fit the context. Sekaran and Bougie underlined that the pretest was very important because the problem of words significantly affected accuracy.

\subsection{Data Collection Method}

Where researchers collect data by giving questions - questions related to the use of social media to the buyer's decision in an online store (Instagram). Researchers make a questionnaire model using a Likert scale which according to (Sugiyono, 2012) this scale is used to measure people's attitudes, opinions and perceptions of social phenomena. The answers to each instrument item that has gradations from very positive to very negative in the form of words include:

Table 1: Attributes of Cleveland dataset

\begin{tabular}{|c|c|}
\hline Information & Score \\
\hline Strongly Agree & 5 \\
\hline Agree & 4 \\
\hline Neutral & 3 \\
\hline Disagree & 2 \\
\hline Strongly Disagree & 1 \\
\hline
\end{tabular}

\subsection{Machine Learning Technique}

Measurement of this research variable by testing the hypothesis of usefulness variables (x1), ease of use variable (x2), social media behavior variable (x3) on intention to buy (y) with an error tolerance level of $0.05(\mathrm{e}=0,05)$.

\section{RESULT AND ANALYSIS}

\subsection{Responded Profile}

This study collected data with a sample of 100 people who used Instagram to provide responses. Respondents by sex were $61.8 \%$ female, and $38.2 \%$ male. Respondents were based on age $8.8 \%$ aged $10-20$ years, $78.4 \%$ aged $21-30$ years, $12.7 \%$ aged 31-40 years. Respondents based on income $20.6 \%$ of 1 million - 2,999 million, $10.8 \%$ of 3 million - 4,999 million, $31.4 \%$ of 5 million $-6,999$ million, $37.3 \%$ of $>7$ million. Active respondents on social media Instagram 8.8\% with $<1$ year, $22.5 \%$ with $1-2$ years, $32.4 \%$ with $3-4$ years, $36.3 \%$ with $>5$ years.

\subsection{Test Validity}

The validity of a test concerns whether the test actually measures what is being measured. The point is how far a test is able to reveal precisely the characteristics or the actual state of the measuring object, will depend on the level of validity of the test to be measure. From the data obtained, the researchers tested the indicators of the usefulness variable (x1), ease of use variable (x2), social media behavior variable (x3) against 
Hans Kristian et al., International Journal of Emerging Trends in Engineering Research, 8(2), February 2020, 598 - 601

intention to buy variable (y) use SmartPls with a significance level of 0.05 .

Table 2: Test Validity Result

\begin{tabular}{|l|l|l|l|}
\hline Variable & P-value & Error & Information \\
\hline Usefulness & 0,439 & 0,05 & Not Valid \\
\hline Ease Of Use & 0,284 & 0,05 & Not Valid \\
\hline $\begin{array}{l}\text { Social Media } \\
\text { Behavior }\end{array}$ & 0,000 & 0,05 & Valid \\
\hline $\begin{array}{l}\text { Intention to } \\
\text { buy }\end{array}$ & 0,000 & 0,05 & Valid \\
\hline
\end{tabular}

\subsection{Hypothesis Test}

SmartPls analysis results, shown in Figure 4.1

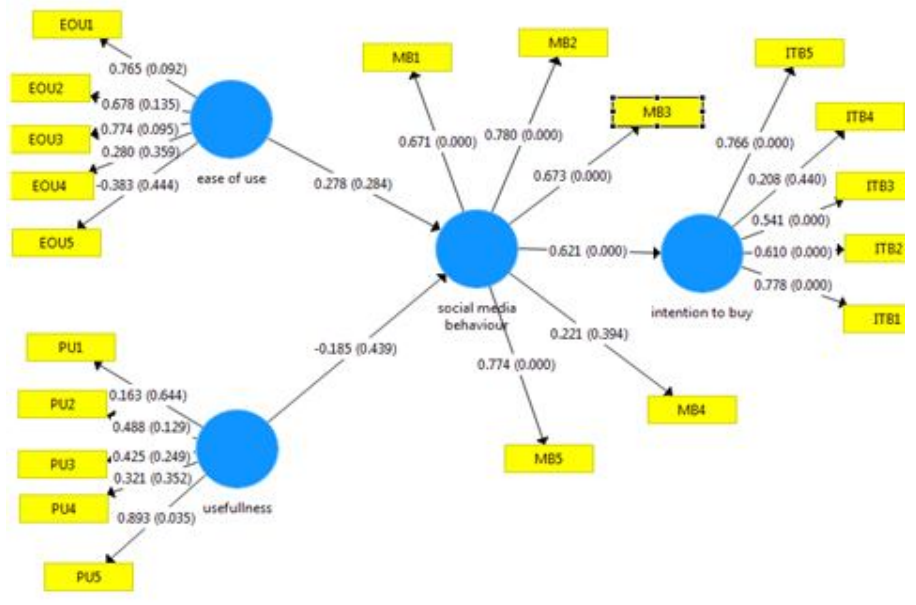

Figure 3: SmartPls Hypothesis Test Results

SmartPls from the calculation results show that:

-H1: The effect of usefulness on social media Behavior shows no effect because the $\mathrm{P}$ value is greater than 0.05

- H2: The effect of Ease of Use on social media behavior shows no effect because the $\mathrm{P}$ value is greater than 0.05

- H3: The effect of social media behavior on intention to buy shows influence because the $\mathrm{P}$ value is less than 0.05

\section{CONCLUSION}

In this study, TAM predictors are proposed to be able to find out the intention of buyers on social media Instagram among perceived ease of use, perceived usefulness and social media behavior. It may be concluded that Instagram facilitates the online shop and it's user behavior shows an influence on intention to buy because the $\mathrm{P}$ value is smaller than 0.05 , also based on data obtained that $66.7 \%$ of active users of Instagram have bought products in the online store.

\section{REFERENCES}

1. Handayani, Rini. 2007, "AnalisisFaktor-Faktor yang Mempengaruhi Minat Pemanfaatan Sistem Informasi”. SNA X. UNHAS Makasar 26-28 Juli. STIE Atma Bhakti Surakarta.

2. Jogiyanto, HM. (2008). Sistem Informasi Keperilakuan (edisi revisi). Yogyakarta: Andi Yogya.

3. Leeflang, P.; Verhoef, P.; Dahsltröm, P.; Freundt, T. Challenges and solutions for marketing in a digital era. Eur. Manag. J. 2014, 32, 1-12. [CrossRef]. https://doi.org/10.1016/j.emj.2013.12.001

4. Salpini, C. (2017). Study: Instagram influences almost $75 \%$ of user purchase decisions. https://www.retaildive.com/news/studyinstagram-influe nces-almost-75-of-user-purchasedecisions/503336 [Accessed 4 January, 2017].

5. P. Surendran, "Technology Acceptance Model: A Survey of Literature", 2012.

6. V. Venkatesh and F. D. Davis, "A theoretical extension of the technology acceptance model: four longitudinal field studies," Management science, vol. 46, pp. 186-204, 2000. https://doi.org/10.1287/mnsc.46.2.186.11926

7. F. D. Davis, "Perceived usefulness, perceived ease of use, and user acceptance of information technology," MIS quarterly, pp. 319-340, 1989. https://doi.org/10.2307/249008 